\title{
Gyroskopiske konsekvenser
}

\section{Ragnild Lome}

\author{
Mark Seltzer \\ The Official World \\ Duke University Press, 2016
}

Coverbildet til litteraturhistorikeren Mark Seltzers nyeste bok, The Official World (2016), er hentet fra performanceverket $A b$ solute Helligkeit av kunstneren Naoko Tanaka. Tanakas performanceverk består av et rom med en bevegelig lyskilde, som lyser opp nye verdener fra forskjellige steder - bak et skrivebord eller under en stol kommer forunderlige tablåer til syne. Tittelen på verket, direkte oversatt «absolutt lyssatt», er hentet fra astronomiens metode for å oppdage nye planeter, som er umulig å se for det blotte øye, men er mulig å finne frem til via en kombinasjon av moderne teknologi og matematiske modeller.

Selv sier kunstneren at verket handler om tenkningens uforutsigbarhet, som i likhet med lyskilden svaier fram og tilbake og i korte øyeblikk får skarpe bilder til å fremtre for publikum. Når Mark Seltzer velger å avbilde verket på forsiden av sin bok, har det kanskje mindre med den plutselige muligheten for erkjennelse å gjøre, som med det faktum at Tanakas verk på samme tid tvinger beskueren til å se på projeksjonene på veggen og til å lokalisere projeksjonenes utgangspunkt. Bildene vi ser projisert 
på de hvite veggene kan alltid tilbakeføres til et punkt i rommet. Vi loopes stille inn i selvrefleksjonens forunderlige hamsterhjul.

Historien til - og de estetiske konsekvensene av - denne indirekte og selvrefleksive metoden for å se, er Mark Seltzers undersøkelsesobjekt. Sentralt i utforskningen står den amerikanske forfatteren og tegneserieskaperen Patricia Highsmith, sammen med forfattere som Tom McCarthy, Kazuo Ishiguro, Agatha Christie og Karl Ove Knausgård. I tillegg sørger instrumenter som gyroskopet, teknologier og fenomener som diktafonen, telefonsvareren, twitter, kjedebrev, spillteori og selskapsspill, for å understøtte Seltzers tese om hva som kjennetegner den særegne selvrefleksive måten å oppfatte virkeligheten på i den sene informasjonsalderen, eller den «offisielle verden».

En offisiell verden er nemlig ifølge Seltzer en verden som ikke har noen utside, ingen privatsfære og ingen dybde. Betegnelsen henviser til den fase som følger etter Max Webers «the second modernization», og Seltzers begrep passer dermed sammen med periodiserende begreper som «refleksiv modernisme» av Anthony Giddens og Ulrich Bech: vår tid er ikke kjennetegnet av søket etter nye ressurser og utvidelser av horisonter, men snarere av forsøk på å bruke de ressursene vi har på en mer effektiv måte. Mens de gamle tyske romantikerne gjerne definerte kunsten som et medium som hele tiden reflekterte over seg selv, har det i «den offisielle verden» gått inflasjon i refleksjonen. Refleksjon er blitt cheap, om ikke helt gratis. Utbredelsen av refleksjonen som default i kulturen henger sammen med moderne styringsteknologi og suksessen til kybernetiske eksperimenter: både tekniske og organiske systemer overvåker og justerer seg selv i uendelige feedbacklooper i dag. Refleksjon er med andre ord blitt en operasjon som foregår overalt i naturen og kulturen, og er ikke noe som utmerker kunstverket spesielt, hevder Seltzer. Hele verden består av myriader av selv-refleksive modeller, og det er i siste instans disse modellene som utgjør hva vi kaller virkelighet.

Det er dermed troen på denne allestedsnærværende refleksjonen og på muligheten for modellering av virkeligheten, som Seltzer kaller «den offisielle verden». Boken er delt opp i fem de- 
ler, som hver inneholder et par kapitler. Den første delen bærer navnet «The Daily Planet» og presenterer hovedtrekkene i betegnelsen «den offisielle verden». Del to, «Stationary Carousels and Chain letters», har fokus på ego-tekniske medier - Seltzers (og Peter Sloterdijks) navn på sosiale medier - som blant annet handler om antropoteknikk, altså teknologi utviklet for å forbedre enkeltpersoner, som opprinnelig ble utviklet i Sovjet på 1920-tallet. Del tre handler om sosiale systemer à la Niklas Luhmann og del fire roterer rundt den særlige refleksive modus som kjennetegner den offisielle verden. Siste del omtaler den postoffisielle verden, hvor blant annet Karl Ove Knausgårds Min Kamp leses, som et eksempel på den leden og tilbaketrekningen den offisielle verden produserer i individer.

I Patricia Highsmiths produksjon har Seltzer funnet et særlig krystallklart eksempel på et forfatterskap som helt siden 1950-tallet har jobbet med modellering og skalering av virkeligheten: «the paradoxical economy of Highsmiths narrative mode takes as given the modalization of the world: it absolutizes perspective and scale, and the reflexivity that goes with them»(182), skriver Seltzer. Det er særlig Highsmiths krimfortellinger som fascinerer han. Krimsjangeren fungerer som en slags «perceptual blueprint of this world», idet den hele tiden forsøker å nedskalere verden til menneskene. «Looking, showing, wondering, and realizing in Highsmith looks like this: the correlationism by which the human observer is the measure of all things, not least in a novel in which hundreds of sentences have the phrases 'he thought', or 'he realized' attached to them». Krimsjangeren prøver kontinuerlig å tilpasse «the world to human size» og markerer samtidig «the official limits of that world» (168). Samme modellerte virkelighet, om enn ikke like elegant utført og intellektuelt stimulerende som hos Highsmith, finner man i en annen krimlegendes romaner, Agatha Christies, hvis poetikk kan beskrives som en «observation and re-enactment», hevder den amerikanske akademikeren.

Bokens tittel, og hovedbegrep, «den offisielle verden» minner oss også om kontorlandskapet via den engelske termen «office». Kontoret dukker ifølge Seltzer opp overalt som scene i 
litteraturen fra den siste halvdelen av 1900-tallet og er, som krimsjangeren, uttrykk for en utforskning og en tro på en modellerbar og skalerbar verden. På kontorer, som på åsteder, modelleres virkeligheten hele tiden av registrert data. Et kontor er «a working model of an antiseptic modernity and its indoor social life». Kontoret er en miniatyr av verden utenfor, som ikke egentlig behøver verden utenfor, men har sin egen særlige operative modus. Kontorene skaper en «corridor-world», en verden «that coordinates at every point bodies, reports, communicative media, and spatial arrangements». Kontoret er «the administrative ground floor of a self-denoting world», et «uncanny space» med referanse til Kafkas uendelige trapper og labyrinter i Slottet og Prosessen. Kort sagt, er kontoret en skalerbar versjon av virkeligheten, et system i systemet.

Når Seltzer leser Hightsmith, Kafka og Christie som reaksjoner og videretenkninger av medieteknologiske endringer, gjør han det uten en stringent kobling til konkrete medier, men snarere til en mer abstrakt idé om medier og mediesystemer. På et overordnet plan skriver Seltzer seg dermed inn i en forlengelse av Friedrich Kittlers tese om at medier determinerer vår situasjon: estetikken avslører hvordan vi operasjonaliserer verden, samtidig som blikket alltid reproduseres på et materielt, medieteknologisk nivå. Styrken ved boken er således verken en medieteoretisk eller metodologisk klarhet, snarere er det den særlige lesemåten til Seltzer som utmerker seg, og som man kjenner igjen om man har lest klassikeren Bodies and Machines (1991). Dér kryssleste han blant annet fagforeningsrapporter fra minearbeiderne og Henry James-romaner for å komme nærmere endringen i oppfattelsen av handlekraft og risikovurdering i 1800-tallets USA. I The Official World samleser han populærvitenskapelige bøker, krim, spillteori og teknologihistorie. Metoden hans kan kanskje beskrives som en eklektisk lesemåte med en løs mediehistorisk base; den overordnede tesen om hvordan blikket endres i den offisielle verden driver lesningen av skjønnlitteraturen framover, samtidig som det er skjønnlitteraturen som bærer størsteparten av bevisbyrden for denne endrede måten å se på. 
Noen steder blir det vanskelig å følge de konkrete sprangene til Seltzer, og av og til blir språket dessuten unødvendig komplisert og pregnant. Det kan lett bli enten banalt eller mystifiserende når Seltzer kaller vår tid for «media union», en tid hvor stadig mer er «conditioned by speed, and repeatability, and by a permanent, and asymptiotically continious connectedness». Andre ganger kan det virke som om de finjusterte poengene forsvinner i altfor generelle eksempler. Som for eksempel i kapittelet «Men in self-curved space», hvor Seltzer skriver om Berlinmurens fall. Det var som om, skriver Seltzer, ryktene om at muren var fallet og grensene var åpnet, førte til at muren falt og at grensene ble åpnet: "Wishful thinking, seeded by the news, with the thinking part installed later. And effects with the intentions put in later too: officials on both West and East sides quickly, of course, took credit for die Wende - the turning point - in German and world history». Når man leser dette, spør man seg om ikke årsakskjeden alltid er kaotisk når politiske omveltninger skjer, og hva egentlig Berlinmurens fall kan brukes som eksempel på.

Forankret i bokens overordnede tese, blir imidlertid eksemplenes banalitet omvandlet til en styrke. Seltzer tankesprang er ikke først og fremst argumenter for en verden i en evig feedbackloop, men en oppfattelse av verden som værende i en tilstand av konstant remodellering, evig påvirkelig av oss selv og mediene. Hvorvidt media eller rykter faktisk kan endre verden, er underordnet oppfattelsen av at vår offisielle verden kan regenere seg i selv-refleksive modeller. Seltzers bok handler derfor om den utbredte opplevelsen i dag, av at ting rapporterer og modellerer seg selv, og at vi, om vi vil eller ei, er fanget i dens stadig mer intrikate selvrefleksive system via stadig mer invasive feedbacklooper. Ved således å forsøke å sirkle inn hvordan de medieteknologiske betingelsene, følelsene og blikket de siste 60 årene har endret seg og blitt organisk vevet inn i hverandre, nærmer Seltzer seg mot slutten av The Official World affektteorien, som nettopp forsøker å ta følelser alvorlig som historiske fenomener.

Det er på ingen måte en oppløftende diagnose Seltzer stiller på vår tid. Livet i en offisiell verden er tett sammenkoblet med 
våre drømmer og følelser, og drømmene og begjærene denne selv-refleksive status quo skaper i oss, fremstår verken som særlig produktive eller framtidsrettede. Følelsen av å kunne bli avslørt, og uten egentlig å ville det, ha muligheten til å mikromanage verdens hendelser, skaper porøse oppfattelser av egen handlekraft. Å forstå disse komplekse sammenhengene mellom avmakt, handlekraft og de underliggende medieteknologiske betingelsene later til å bli viktigere fremover, i samfunnet, for den individuelle eksistens, og også i forskningen. Som ledd i denne komplekse utforskningen utgjør Seltzers bok en uunngålig brikke. 